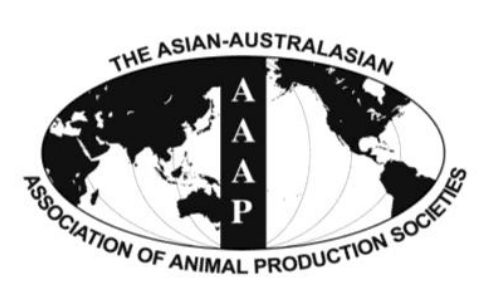

Open Access

Asian Australas. J. Anim. Sci.

Vol. 27, No. 6 : $871-879$ June 2014

http://dx.doi.org/10.5713/ajas.2013.13669

www.ajas.info

pISSN 1011-2367 elSSN 1976-5517

\title{
Determination and Prediction of Digestible and Metabolizable Energy from the Chemical Composition of Chinese Corn Gluten Feed Fed to Finishing Pigs
}

\author{
T. T. Wang ${ }^{1}$, D. W. Liu ${ }^{1,2}$, C. F. Huang ${ }^{1}$, L. Liu ${ }^{1}$, X. S. Piao ${ }^{1}$, and F. L. Wang ${ }^{1, *}$ \\ ${ }^{1}$ State Key Laboratory of Animal Nutrition, Ministry of Agriculture Feed Industry Centre, \\ China Agriculture University, Beijing 100193, China
}

\begin{abstract}
Two experiments were conducted to determine the digestible energy (DE) and metabolizable energy (ME) contents of corn gluten feed (CGF) for finishing pigs and to develop equations predicting the DE and ME content from the chemical composition of the CGF samples, as well as validate the accuracy of the prediction equations. In Exp. 1, ten CGF samples from seven provinces of China were collected and fed to 66 finishing barrows (Duroc $\times$ Landrace $\times$ Yorkshire) with an initial body weight (BW) of $51.9 \pm 5.5 \mathrm{~kg}$. The pigs were assigned to 11 diets comprising one basal diet and 10 CGF test diets with six pigs fed each diet. The basal diet contained corn $(76 \%)$, dehulled soybean meal $(21 \%)$ and premix (3\%). The ten test diets were formulated by substituting $25 \%$ of the corn and dehulled soybean meal with CGF and contained corn (57\%), dehulled soybean meal (15.75\%), CGF (24.25\%) and premix (3\%). In Exp. 2, two additional CGF sources were collected as validation samples to test the accuracy of the prediction equations. In this experiment, 18 barrows (Duroc $\times$ Landrace $\times$ Yorkshire) with an initial BW of $61.1 \pm 4.0 \mathrm{~kg}$ were randomly allotted to be fed either the basal diet or two CGF containing diets which had a similar composition as used in Exp. 1. The DE and ME of CGF ranged from 10.37 to $12.85 \mathrm{MJ} / \mathrm{kg}$ of dry matter (DM) and 9.53 to $12.49 \mathrm{MJ} / \mathrm{kg}$ of DM, respectively. Through stepwise regression analysis, several prediction equations of DE and ME were generated. The best fit equations were: $\mathrm{DE}, \mathrm{MJ} / \mathrm{kg}$ of $\mathrm{DM}=18.30-0.13$ neutral detergent fiber -0.22 ether extract, with $\mathrm{R}^{2}$ $=0.95$, residual standard deviation $(\mathrm{RSD})=0.21$ and $\mathrm{p}<0.01$; and $\mathrm{ME}, \mathrm{MJ} / \mathrm{kg}$ of $\mathrm{DM}=12.82+0.11$ Starch -0.26 acid detergent fiber, with $\mathrm{R}^{2}=0.94, \mathrm{RSD}=0.20$ and $\mathrm{p}<0.01$. These results indicate that the DE and ME content of CGF varied substantially but the DE and ME for finishing pigs can be accurately predicted from equations based on nutritional analysis. (Key Words: Corn Gluten Feed, Finishing Pigs, Digestible Energy, Metabolizable Energy, Prediction Equations)
\end{abstract}

\section{INTRODUCTION}

Corn gluten feed (CGF) is a by-product of the wet milling of corn for starch or the ethanol industry, and is composed primarily of corn bran and steep liquor (Scott et al., 1997). It is widely used as a livestock feed (Evvard, 1920; Stock et al., 1999). The inclusion of CGF has been recommended at levels up to $20 \%$ of the diet for growing

\footnotetext{
* Corresponding Author: F. L. Wang. Tel: +86-010-62733586, Fax: +86-010-62733586, E-mail: wangfl@ cau.edu.cn

2 The College of Agriculture, Dezhou University, Dezhou, Shandong 253023, China.

Submitted Oct. 24, 2013; Revised Jan. 7, 2014; Accepted Feb. 14, 2014
}

pigs (Castaing et al., 1990) and 30\% for finishing pigs without reducing performance (Yen et al., 1971).

However, the average nutritional values of CGF were misleading because they could probably be affected by the ratio of bran and steep liquor (Ham et al., 1995). Its highly variable content of protein, poor amino acid profile and high level of fiber limit its use in monogastric animals (De Godoy et al., 2009). The uncertain nutrient contents directly affect the consistency of digestible energy (DE) and metabolizable energy (ME) and either cannot meet the requirement of pigs or lead to the waste of feed.

Using regression equations for DE and ME to predict the available energy has been reported to solve this problem (Noblet et al., 1993; Le Goff and Noblet, 2001; Anderson et

Copyright $@ 2014$ by Asian-Australasian Journal of Animal Sciences This is an open-access article distributed under the terms of the Creative Commons Attribution Non-Commercial License (http://creativecommons.org/licenses/by-nc/3.0/), which permits unrestricted non-commercial use, distribution, and reproduction in any medium, provided the original work is properly cited. 
al., 2012). The regression equations for growing-finishing pigs either could only predict the DE and ME of the diets containing CGF (Noblet and Perez, 1993; Le Goff and Noblet, 2001) or were established on the corn by-products with only one CGF sample (Young et al., 1977; Anderson et al., 2012). However, these two kinds of equations could not estimate accurately the energy values of feedstuffs, and specific equations should be established (Noblet et al., 1993). For these reasons, the objectives of this experiment were to determine the chemical composition, DE and ME of $10 \mathrm{CGF}$ samples to finishing pigs and to develop prediction equations for energy content based on the chemical composition of individual CGF.

\section{MATERIALS AND METHODS}

\section{General procedures}

Two experiments were conducted in the Fengning Experimental Base (China Agricultural University, Beijing, China). Pigs were individually placed in stainless-steel metabolism crates $(1.20 \times 0.70 \times 0.96 \mathrm{~m})$ that allowed for the total, but separate, collection of feces and urine for an adjustment period of seven days followed by a 5-d collection period. The crates were installed with one drinking nipple and one feeding trough. In an environmentally controlled room, the temperature was maintained at $22 \pm 2{ }^{\circ} \mathrm{C}$.

In Exp. 1, ten CGF samples were obtained from 10 starch factories in the seven provinces of China where the primary starch industries are located in order to obtain as much variability as possible. The chemical composition of the different CGF sources are shown in Table 1 and 2. Sixty-six crossbred (Duroc $\times$ Landrace $\times$ Yorkshire) barrows weighing $51.9 \pm 5.5 \mathrm{~kg}$ were assigned to 11 diets comprising of one basal diet and 10 CGF test diets with six pigs fed each diet.

The basal diet was based on corn $(76 \%)$, soybean meal $(21 \%)$, and premix $(3 \%)$. The ten test diets were formulated to contain $24.25 \%$ CGF, which replaced $25 \%$ of the energy supplied by corn and de-hulled soybean meal in the basal diet. The inclusion level of CGF was determined according to a preliminary experiment which found that $25 \%$ was the highest inclusion level considering the risk of feed refusals. The composition and nutrient levels of the experimental diets are shown in Table 3 and 4.

For Exp. 2, another two CGF samples which were different from the previous ten samples were collected to validate the accuracy of the prediction equations in Exp. 1. Eighteen barrows (Duroc $\times$ Landrace $\times$ Yorkshire) were fed either the basal diet or one of the two test diets and the composition of the experimental diets were similar as that used in Exp. 1.

In the two studies, the daily feed allowance equaled $4 \%$ of body weight (Adeola, 2001). The amounts of feed, refusals and spillage for each pig were recorded. At 8:00 h and 17:00 h, equal meals were provided to the pigs, and the water was accessible freely throughout the trial. During the 5 -d fecal and urine collection period, the feces were collected immediately upon appearance in the metabolism crates from 7:00 $\mathrm{h}$ to $21: 00 \mathrm{~h}$ and were placed into the plastic bags. The urine was collected in buckets under the crates and contained $50 \mathrm{~mL} 6 \mathrm{~N} \mathrm{HCl}$ all the day. The feces and $10 \%$ of the urine were stored at $-20^{\circ} \mathrm{C}$ after the daily collection. At the end of the collection period, the feces of each pig over the 5-d period were thawed, mixed and weighed. Then, representative fecal sub-samples were

Table 1. Analyzed composition of corn gluten feed in Exp. 1

\begin{tabular}{|c|c|c|c|c|c|c|c|c|c|c|c|c|}
\hline \multirow{2}{*}{ Items } & \multicolumn{10}{|c|}{ Corn gluten feed sources $^{1}$} & \multirow{2}{*}{ Mean } & \multirow{2}{*}{$\mathrm{CV}$} \\
\hline & 1 & 2 & 3 & 4 & 5 & 6 & 7 & 8 & 9 & 10 & & \\
\hline $\mathrm{DM}$ & 92.33 & 90.72 & 89.74 & 92.27 & 90.55 & 92.56 & 94.70 & 92.94 & 92.20 & 91.36 & 91.94 & 1.54 \\
\hline \multicolumn{13}{|c|}{ Composition (\% of DM) } \\
\hline $\mathrm{CP}$ & 22.20 & 21.69 & 21.16 & 21.04 & 24.75 & 20.89 & 20.85 & 17.21 & 27.18 & 21.29 & 21.83 & 12.02 \\
\hline Ether extract & 8.08 & 6.74 & 3.97 & 3.10 & 2.87 & 2.78 & 5.30 & 4.71 & 2.21 & 2.41 & 4.22 & 46.84 \\
\hline Crude fiber & 9.90 & 10.92 & 14.13 & 9.77 & 10.88 & 9.11 & 11.05 & 16.47 & 7.44 & 12.33 & 11.20 & 23.07 \\
\hline NDF & 37.15 & 42.24 & 49.28 & 38.34 & 38.79 & 41.96 & 40.15 & 52.91 & 41.74 & 47.97 & 43.05 & 12.18 \\
\hline $\mathrm{ADF}$ & 10.74 & 13.64 & 13.46 & 10.60 & 10.69 & 12.50 & 11.94 & 15.25 & 11.90 & 12.61 & 12.33 & 12.14 \\
\hline Ash & 9.07 & 10.04 & 4.30 & 5.84 & 6.98 & 6.24 & 7.97 & 4.13 & 7.77 & 6.96 & 6.93 & 27.42 \\
\hline Calcium & 0.08 & 0.06 & 0.06 & 0.10 & 0.15 & 0.15 & 0.21 & 0.16 & 0.13 & 0.07 & 0.12 & 43.59 \\
\hline Total phosphorus & 0.94 & 0.84 & 0.77 & 0.84 & 0.89 & 0.81 & 0.48 & 0.54 & 1.13 & 1.05 & 0.83 & 24.30 \\
\hline Starch & 10.31 & 8.01 & 8.75 & 19.64 & 13.15 & 16.67 & 9.95 & 7.75 & 4.19 & 6.32 & 10.47 & 45.36 \\
\hline Sodium $(\mathrm{mg} / \mathrm{kg})$ & 180 & 3012 & 19 & 224 & 710 & 123 & 285 & 572 & 413 & 311 & 458 & 45 \\
\hline Sulfur (mg/kg) & 666 & 654 & 684 & 657 & 842 & 692 & 1014 & 845 & 1037 & 661 & 921 & 16 \\
\hline GE (MJ/kg) & 19.40 & 18.94 & 19.31 & 18.57 & 18.55 & 18.42 & 19.04 & 19.26 & 18.37 & 18.24 & 18.81 & 2.29 \\
\hline
\end{tabular}

$\mathrm{CV}$, coefficient of variation; DM, dry matter; CP, crude protein; NDF, neutral detergent fiber; ADF, acid detergent fiber; GE, gross energy.

${ }^{1}$ Sources 1 to 6 were collected from different starch industries located in Inner Mongolia, Jilin and Shandong Provinces of China, respectively. Sources 7 to 10 were collected from Shanxi, Hebei, Henan and Shaanxi Provinces of China, respectively. 
Table 2. Analyzed amino acid composition of corn gluten feeds in Exp. 1 (\%, DM basis)

\begin{tabular}{|c|c|c|c|c|c|c|c|c|c|c|c|c|}
\hline & \multicolumn{10}{|c|}{ Corn gluten feed sources $^{1}$} & \multirow{2}{*}{ Mean } & \multirow{2}{*}{$\mathrm{CV}$} \\
\hline & 1 & 2 & 3 & 4 & 5 & 6 & 7 & 8 & 9 & 10 & & \\
\hline$\overline{\mathrm{CP}}$ & 22.20 & 21.69 & 21.16 & 21.04 & 24.75 & 20.89 & 20.85 & 17.21 & 27.18 & 21.29 & 21.83 & 12.02 \\
\hline \multicolumn{13}{|c|}{ Indispensable amino acids } \\
\hline Arginine & 1.13 & 0.95 & 1.04 & 0.79 & 0.69 & 0.64 & 0.50 & 0.75 & 1.29 & 0.50 & 0.83 & 32.28 \\
\hline Histidine & 0.73 & 0.70 & 0.62 & 0.63 & 0.72 & 0.65 & 0.48 & 0.61 & 0.98 & 0.59 & 0.67 & 19.26 \\
\hline Isoleucine & 0.68 & 0.66 & 0.60 & 0.64 & 0.76 & 0.64 & 0.59 & 0.50 & 0.83 & 0.61 & 0.65 & 13.98 \\
\hline Leucine & 2.01 & 1.86 & 1.84 & 1.93 & 2.28 & 1.95 & 1.75 & 1.52 & 2.42 & 1.84 & 1.94 & 13.23 \\
\hline Lysine & 0.75 & 0.70 & 0.72 & 0.52 & 0.65 & 0.56 & 0.36 & 0.54 & 0.95 & 0.46 & 0.62 & 26.92 \\
\hline Methionine & 0.35 & 0.34 & 0.30 & 0.30 & 0.38 & 0.31 & 0.29 & 0.26 & 0.41 & 0.28 & 0.32 & 14.60 \\
\hline Phenylalanine & 0.72 & 0.72 & 0.68 & 0.70 & 0.83 & 0.67 & 0.63 & 0.57 & 0.90 & 0.62 & 0.70 & 13.81 \\
\hline Threonine & 0.82 & 0.80 & 0.75 & 0.78 & 0.91 & 0.80 & 0.69 & 0.67 & 1.06 & 0.84 & 0.81 & 13.86 \\
\hline Tryptophan & 0.10 & 0.11 & 0.11 & 0.11 & 0.10 & 0.07 & 0.08 & 0.07 & 0.08 & 0.08 & 0.09 & 18.00 \\
\hline Valine & 1.14 & 1.09 & 0.99 & 1.01 & 1.28 & 1.06 & 0.98 & 0.90 & 1.46 & 1.06 & 1.10 & 14.86 \\
\hline \multicolumn{13}{|c|}{ Dispensable amino acids } \\
\hline Alanine & 1.52 & 1.61 & 1.44 & 1.66 & 1.79 & 1.52 & 1.45 & 1.07 & 1.80 & 1.63 & 1.55 & 13.48 \\
\hline Aspartate & 1.45 & 1.25 & 1.07 & 1.14 & 1.35 & 1.00 & 0.92 & 0.96 & 1.71 & 0.98 & 1.18 & 21.69 \\
\hline Cystine & 0.46 & 0.44 & 0.43 & 0.39 & 0.51 & 0.44 & 0.41 & 0.43 & 0.60 & 0.46 & 0.46 & 12.89 \\
\hline Glutamic acid & 3.38 & 3.26 & 3.23 & 3.19 & 3.65 & 3.12 & 2.79 & 2.66 & 4.11 & 2.97 & 3.24 & 12.97 \\
\hline Glycine & 0.95 & 0.94 & 0.85 & 0.91 & 1.07 & 0.88 & 0.79 & 0.78 & 1.26 & 0.94 & 0.94 & 15.13 \\
\hline Proline & 1.93 & 1.80 & 1.85 & 1.81 & 2.23 & 2.01 & 1.61 & 1.66 & 2.59 & 2.06 & 1.96 & 14.80 \\
\hline Serine & 0.90 & 0.87 & 0.84 & 0.78 & 0.94 & 0.86 & 0.76 & 0.70 & 1.17 & 0.86 & 0.87 & 14.51 \\
\hline Tyrosine & 0.53 & 0.55 & 0.48 & 0.38 & 0.39 & 0.35 & 0.27 & 0.35 & 0.56 & 0.28 & 0.42 & 25.95 \\
\hline
\end{tabular}

$\mathrm{DM}$, dry matter; $\mathrm{CV}$, coefficient of variation; $\mathrm{CP}$, crude protein.

${ }^{1}$ Sources 1 to 6 were collected from different starch industries located in Inner Mongolia, Jilin and Shandong Provinces of China, respectively. Sources 7 to 10 were collected from Shanxi, Hebei, Henan and Shaanxi Provinces of China, respectively.

weighed and dried in a $65^{\circ} \mathrm{C}$ forced-air oven and ground through a $1-\mathrm{mm}$ screen. Likewise, $100 \mathrm{~mL}$ of urine samples were thawed and placed into the vessel for chemical analysis. The procedures for the collection and sample preparation of feces and urine were conducted according to the methods described by Ji et al. (2012) and Li et al. (2012).

Table 3. Composition of the experimental diets in Exp. 1 and 2 (\%, as-fed)

\begin{tabular}{|c|c|c|}
\hline Items & Basal diet & Experimental diets \\
\hline$\overline{\text { Corn }}$ & 76.00 & 57.00 \\
\hline Dehulled soybean meal & 21.00 & 15.75 \\
\hline Corn gluten feed & - & 24.25 \\
\hline Dicalcium phosphate & 1.10 & 1.10 \\
\hline Limestone & 0.90 & 0.90 \\
\hline Sodium chloride & 0.30 & 0.30 \\
\hline Choline chloride & 0.20 & 0.20 \\
\hline $\begin{array}{l}\text { Vitamin and } \\
\text { micro mineral premix }{ }^{1}\end{array}$ & 0.50 & 0.50 \\
\hline \multicolumn{3}{|c|}{$\begin{array}{l}{ }^{1} \text { Premix provided the following per kg of complete diet: vitamin A, 5,512 } \\
\mathrm{IU} \text {; vitamin } \mathrm{D}_{3}, 2,200 \mathrm{IU} \text {; vitamin E, } 30 \mathrm{IU} \text {; vitamin } \mathrm{K}_{3}, 2.2 \mathrm{mg} \text {; vitamin } \\
\mathrm{B}_{12}, 27.6 \mu \mathrm{g} \text {; riboflavin, } 4 \mathrm{mg} \text {; pantothenic acid, } 14 \mathrm{mg} \text {; niacin, } 30 \mathrm{mg} \text {; } \\
\text { choline chloride, } 400 \mathrm{mg} \text {; folacin, } 0.7 \mathrm{mg} \text {; thiamine } 1.5 \mathrm{mg} \text {; pyridoxine } 3 \\
\mathrm{mg} \text {; biotin, } 44 \mu \mathrm{g} \text {; } \mathrm{Mn}, 40 \mathrm{mg}(\mathrm{MnO}) ; \mathrm{Fe}, 75 \mathrm{mg}\left(\mathrm{FeSO}_{4} \cdot \mathrm{H}_{2} \mathrm{O}\right) ; \mathrm{Zn}, 75 \\
\mathrm{mg}(\mathrm{ZnO}) ; \mathrm{Cu}, 100 \mathrm{mg}\left(\mathrm{CuSO}_{4} \cdot 5 \mathrm{H}_{2} \mathrm{O}\right) ; \mathrm{I}, 0.3 \mathrm{mg}(\mathrm{KI}) ; \mathrm{Se}, 0.3 \mathrm{mg} \\
\left(\mathrm{Na}_{2} \mathrm{SeO}_{3}\right) \text {. }\end{array}$} \\
\hline
\end{tabular}

\section{Chemical analysis}

The methods for analyzing the nutritional levels of samples were similar to the methods described by Ji et al. (2012) and Li et al. (2012). All samples were analyzed in duplicate. All CGF used in this experiment and the experimental diets were analyzed for dry matter (DM) (AOAC method 930.15, 2000), crude protein (CP) (AOAC method 990.03, 2000), ether extract (EE) (Thiex et al., 2003), crude fiber (CF) (AOAC method 978.10, 2000), ash (AOAC method 942.05, 2000), calcium (Ca) (AOAC method 927.02, 2000) and total phosphorous (TP) (AOAC method 965.17, 2000). The concentration of neutral detergent fiber (NDF) and acid detergent fiber (ADF) were determined by using the method described by Van Soest et al. (1991). The samples of CGF, diets, feces and urine were analyzed for gross energy (GE) via an adiabatic oxygen bomb calorimeter (Parr Instruments, Moline, IL, USA).

The CGF were analyzed for 15 amino acids (AOAC, method 999.13, 2000) using an Amino Acid Analyzer (Hitachi L-8900, Tokyo, Japan). Methionine and cysteine (AOAC, method 994.12, 2000) were analyzed using an Amino Acid Analyzer (Hitachi L-8800, Tokyo, Japan). Tryptophan (AOAC, method 998.15, 2000) was analyzed using High Performance Liquid Chromatography (Agilent 1200 Series, Santa Clara, CA). The starch concentration of CGF was analyzed according to the enzymatic method 
Table 4. Analyzed nutrient composition of the experimental diets for Exp. 1

\begin{tabular}{lccccccccccc}
\hline \multirow{2}{*}{ Items } & \multicolumn{10}{c}{ Corn gluten feed sources ${ }^{1}$} \\
\cline { 2 - 12 } & Basal diet & 1 & 2 & 3 & 4 & 5 & 6 & 7 & 8 & 9 \\
\hline DM & 88.94 & 90.06 & 90.13 & 90.15 & 90.35 & 89.84 & 90.30 & 90.11 & 90.33 & 90.57 & 90.23 \\
Composition (\% of DM) & & & & & & & & & & \\
CP & 17.97 & 19.18 & 18.46 & 18.44 & 18.39 & 19.26 & 18.55 & 19.18 & 17.76 & 19.71 & 18.58 \\
Ether extract & 2.28 & 3.67 & 4.17 & 3.46 & 3.09 & 3.20 & 3.12 & 3.76 & 3.69 & 3.09 & 2.93 \\
Crude fiber & 2.59 & 4.21 & 4.49 & 4.63 & 3.92 & 4.13 & 4.30 & 4.24 & 5.65 & 4.30 & 4.81 \\
NDF & 10.25 & 16.33 & 17.80 & 20.43 & 17.63 & 17.82 & 17.95 & 17.04 & 20.74 & 17.77 & 20.05 \\
ADF & 2.90 & 4.41 & 5.00 & 5.49 & 4.98 & 4.95 & 5.39 & 4.73 & 5.70 & 4.93 & 5.54 \\
Ash & 5.24 & 6.37 & 6.41 & 5.19 & 5.81 & 5.87 & 6.26 & 6.23 & 5.35 & 6.13 & 5.88 \\
Calcium & 0.78 & 0.73 & 0.73 & 0.75 & 0.77 & 0.73 & 0.80 & 0.73 & 0.73 & 0.73 & 0.75 \\
Total Phosphorus & 0.57 & 0.72 & 0.65 & 0.64 & 0.67 & 0.66 & 0.73 & 0.58 & 0.59 & 0.73 & 0.72 \\
GE (MJ/kg) & 17.95 & 17.99 & 18.11 & 18.21 & 17.89 & 18.00 & 17.86 & 18.11 & 18.10 & 17.89 & 17.99 \\
\hline
\end{tabular}

DM, dry matter; $\mathrm{CP}$, crude protein; NDF, neutral detergent fiber; ADF, acid detergent fiber; GE, gross energy.

${ }^{1}$ Sources 1 to 6 were collected from different starch industries located in Inner Mongolia, Jilin and Shandong Provinces of China, respectively. Sources 7 to 10 were collected from Shanxi, Hebei, Henan and Shaanxi Provinces of China, respectively.

described by Xiong et al. (1990). The concentrations of sodium and sulfur in CGF were determined using a Polarized Zeeman Atomic Absorption Spectrometer (Hitachi Z2000, Tokyo, Japan).

\section{Calculations}

In the two experiments, the energy-contributing ingredients in the basal diet were corn and soybean meal, which made up $97 \%$ of the basal diet. Therefore, the energy concentration was calculated by dividing the DE and ME of the basal diet by 0.97 . The DE and ME values for each source of CGF were calculated by subtracting the contribution from the control diet in the CGF-containing diets using the difference procedure (Adeola, 2001).

\section{Statistical analysis}

Data were analyzed statistically using the Proc GLM Procedure of SAS (SAS Inst. Inc., NC, USA). Individual pig was as the experimental unit and the nutritional values of the 10 CGF were compared by ANOVA. Stepwise regression procedures of SAS were used to determine the relationship between the chemical composition and DE and ME. The correlation coefficients between chemical composition and DE and ME of corn gluten feed sources was conducted by the Proc CORR procedure. The $\mathrm{R}^{2}$, residual standard deviation (RSD) and $\mathrm{p}$ value were used to define the best equation. In all analysis, a probability of $p<0.05$ was accepted as statistically significant. The level of significance adopted was $1 \%(\mathrm{p}<0.01)$.

\section{RESULTS}

\section{Nutrient composition of corn gluten feed sources in} Exp. 1

The nutrient composition of the CGF varied substantially (Tables 1 and 2). Except DM and GE, the coefficient of variation $(\mathrm{CV})$ of other criteria for the 10 CGF samples were higher than $10 \%$, and the CV of EE, calcium, starch and sodium were greater than $40 \%$ which indicated that the quality of CGF from different provinces and industries had a large variability.

The average content of DM of the 10 CGF samples was 91.94\%. On a DM basis, the content of CP, EE, starch and GE of the 10 samples ranged from 17.21 to $27.18 \%, 2.21$ to $8.08 \%, 4.19$ to $19.64 \%$, and 18.24 to $19.40 \mathrm{MJ} / \mathrm{kg}$, respectively. The mean fiber content including CF, NDF and ADF ranged from 7.44 to $16.47 \%, 37.15$ to $52.91 \%$ and 10.60 to $15.25 \%$, respectively. The concentration of ash, calcium, total phosphorous, sodium and sulfur ranged from 4.13 to $10.04 \%, 0.06$ to $0.21 \%, 0.48$ to $1.13 \%, 18$ to 710 $\mathrm{mg} / \mathrm{kg}$ and 654 to $1037 \mathrm{mg} / \mathrm{kg}$. The CV of both the indispensable and dispensable amino acids were over $10 \%$, but as for the quality of the indispensable amino acids, except arginine, histidine, lysine and tryptophan, the $\mathrm{CV}$ of other amino acids were less than $15 \%$.

The DE, ME, apparent total tract digestibility (ATTD) of energy and ME/DE differed among the 10 sources of CGF from 10.37 to $12.85 \mathrm{MJ}$ of DE/kg of DM, 9.53 to $12.49 \mathrm{MJ}$ of ME/kg of DM, 53.85 to $69.22 \%$ and 85.61 to $97.16 \%$, respectively, which is shown in Table 5 .

\section{Correlations and prediction equations in Exp. 1}

The fiber indicators, including NDF, ADF and CF, had a negative correlation with $\mathrm{DE}$ and $\mathrm{ME}$ but the content of starch had a positive correlation with DE and ME (Table 6). DE had a highly positive correlation with ME with a correlation coefficient of $0.89(\mathrm{p}<0.05)$. But GE had a negative correlation with DE and ME.

Based on the analyzed GE and nutrient composition of CGF and the calculated values for DE and ME, prediction 
Table 5. Energy content and apparent total tract digestibility of GE of corn gluten feeds in Exp. 1

\begin{tabular}{|c|c|c|c|c|c|c|c|c|c|c|c|c|}
\hline \multirow{2}{*}{ Items } & \multicolumn{10}{|c|}{ Corn gluten feed sources ${ }^{1}(n=6)$} & \multirow{2}{*}{ SEM } & \multirow{2}{*}{ p-value } \\
\hline & 1 & 2 & 3 & 4 & 5 & 6 & 7 & 8 & 9 & 10 & & \\
\hline$\overline{\mathrm{DE}}(\mathrm{MJ} / \mathrm{kg}$ as-fed $)$ & 10.80 & 10.04 & 9.70 & 11.86 & 11.15 & 11.28 & 10.98 & 9.64 & 11.25 & 10.33 & 0.65 & 0.25 \\
\hline $\mathrm{DE}(\mathrm{MJ} / \mathrm{kg} \mathrm{DM})$ & 11.69 & 11.07 & 10.81 & 12.85 & 12.31 & 12.18 & 11.60 & 10.37 & 12.20 & 11.31 & 0.70 & 0.33 \\
\hline $\mathrm{ME}(\mathrm{MJ} / \mathrm{kg}$ as-fed $)$ & 10.01 & 9.17 & 9.21 & 11.52 & 10.16 & 10.52 & 10.03 & 8.86 & 9.63 & 9.45 & 0.68 & 0.26 \\
\hline $\mathrm{ME}(\mathrm{MJ} / \mathrm{kg} \mathrm{DM})$ & 10.84 & 10.10 & 10.27 & 12.49 & 11.22 & 11.37 & 10.59 & 9.53 & 10.45 & 10.34 & 0.75 & 0.31 \\
\hline ATTD of GE (\%) & 60.27 & 58.44 & 55.98 & 69.22 & 66.35 & 66.12 & 60.89 & 53.85 & 66.44 & 62.01 & 0.04 & 0.09 \\
\hline $\mathrm{ME} / \mathrm{DE}^{2}(\%)$ & 92.68 & 91.29 & 94.95 & 97.16 & 91.14 & 93.32 & 91.34 & 91.93 & 85.61 & 91.45 & 0.03 & 0.45 \\
\hline
\end{tabular}

GE, gross energy; SEM, standard error of the mean; DE, digestible energy; DM, dry matter; ME, metabolizable energy; ATTD, apparent total tract digestibility.

${ }^{1}$ Sources 1 to 6 were collected from different starch industries located in Inner Mongolia, Jilin and Shandong Provinces of China, respectively. Sources 7 to 10 were collected from Shanxi, Hebei, Henan and Shaanxi Provinces of China, respectively.

${ }^{2} \mathrm{ME} / \mathrm{DE}=$ The ratio of ME to DE.

Table 6. Correlation coefficients between chemical composition and DE and ME of corn gluten feeds ${ }^{1}(\mathrm{n}=6)$

\begin{tabular}{|c|c|c|c|c|c|c|c|c|c|}
\hline Item & $\mathrm{CP}$ & $\mathrm{EE}$ & NDF & $\mathrm{ADF}$ & $\mathrm{CF}$ & Ash & Starch & GE & $\overline{\mathrm{DE}}$ \\
\hline EE & -0.29 & & & & & & & & \\
\hline NDF & -0.54 & -0.20 & & & & & & & \\
\hline $\mathrm{ADF}$ & -0.59 & 0.08 & 0.88 & & & & & & \\
\hline $\mathrm{CF}$ & -0.74 & 0.14 & 0.82 & 0.72 & & & & & \\
\hline Ash & 0.45 & 0.50 & -0.64 & -0.37 & -0.60 & & & & \\
\hline Starch & -0.20 & -0.13 & -0.48 & -0.47 & -0.24 & -0.20 & & & \\
\hline GE & -0.46 & 0.79 & 0.18 & 0.31 & 0.52 & -0.07 & -0.15 & & \\
\hline $\mathrm{DE}$ & 0.57 & -0.39 & -0.80 & -0.86 & -0.82 & 0.22 & 0.62 & -0.60 & \\
\hline ME & 0.22 & -0.28 & -0.70 & -0.79 & -0.58 & 0.01 & 0.87 & -0.40 & 0.89 \\
\hline
\end{tabular}

CP, crude protein; EE, ether extract; NDF, neutral detergent fiber; ADF, acid detergent fiber; CF, crude fiber; GE, gross energy; DE, digestible energy; $\mathrm{ME}$, metabolizable energy.

${ }^{1}$ A correlation whose absolute value is above 0.51 is different from $0(\mathrm{p}<0.05)$.

equations for DE and ME were developed (Table 7). These equations showed that DE in CGF may be predicted from the concentration of fiber or a combination of fiber and some other indicators while the ME may be predicted from the starch content. The single predictor with the highest correlation coefficient for DE was ADF. While for ME, it was starch $(0.74$ for $\mathrm{DE}, \mathrm{p}<0.05 ; 0.76$ for $\mathrm{ME}, \mathrm{p}<0.05$, respectively). Adding more indicators to predict the $\mathrm{DE}$ and ME increased the $\mathrm{R}^{2}$ of the equations. For equations 2, 3 and 7 of $\mathrm{DE}$, the $\mathrm{R}^{2}$ increased from 0.74 to 0.85 to 0.95 , and from equations 9,11 and 12 of $\mathrm{ME}$, the $\mathrm{R}^{2}$ increased from 0.76 to 0.94 to 0.96 . The content of CF or NDF also can be used to predict the DE equations. Furthermore, using the DE value to predict the content of ME obtained a prediction equation with a $\mathrm{R}^{2}$ value of 0.80 and RSD of 0.35 .

\section{The accuracy of the prediction equations in Exp. 2}

The nutrient composition and the determined and predicted DE and ME values of the two CGF sources are listed in Table 8 . The determined DE and ME of the two CGF sources were within the ranges of $\mathrm{DE}$ and ME values determined in Exp. 1.

Equations 6 and 11 from Exp. 1 were selected to predict the DE and ME, respectively. The comparison of the determined available energy values and the predicted values are shown in Table 8 and the relative deviations were less than $5 \%$.

\section{DISCUSSION}

\section{Nutrient composition of corn gluten feed sources in Exp. 1}

There was a large amount of variation among the chemical composition of the 10 CGF sources, which were also different from the values in NRC (2012). One possible reason was the different quality of corn which was used to produce the starch. Corn gluten feed is the by-product of the starch industry and is mainly composed of corn bran and steep liquor (Evvard, 1920; Stock et al., 1999). The corn from different provinces with the different conditions of soil and environment or the various cultivations might result in the different corn bran and steep liquor which directly led to the different chemical composition of CGF (Hull et al., 1996; Pedersen et al., 2007).

Another reason might be the different processing methods used for CGF. In terms of process, the steep liquor 
Table 7. Stepwise regression equations for DE and ME (kcal/kg DM) from chemical composition of corn gluten feeds in Exp. 1 $(\%, \mathrm{DM})$

\begin{tabular}{|c|c|c|c|c|}
\hline No. & Predication equations & $\mathrm{R}^{2}$ & RSD & p-value \\
\hline 1 & $\mathrm{DE}=14.36-0.24 \mathrm{CF}$ & 0.67 & 0.42 & $<0.01$ \\
\hline 2 & $\mathrm{DE}=17.08-0.44 \mathrm{ADF}$ & 0.74 & 0.37 & $<0.01$ \\
\hline 3 & $\mathrm{DE}=17.44-0.43 \mathrm{ADF}-0.12 \mathrm{EE}$ & 0.85 & 0.28 & $<0.01$ \\
\hline 4 & $\mathrm{DE}=13.23-0.21 \mathrm{CF}+0.07 \mathrm{Starch}$ & 0.87 & 0.27 & $<0.01$ \\
\hline 5 & $\mathrm{DE}=9.03-0.10 \mathrm{CF}+0.12 \mathrm{CP}+0.10 \mathrm{Starch}$ & 0.92 & 0.21 & $<0.01$ \\
\hline 6 & $\mathrm{DE}=18.30-0.13 \mathrm{NDF}-0.22 \mathrm{EE}$ & 0.95 & 0.21 & $<0.01$ \\
\hline 7 & $\mathrm{DE}=18.30-0.05 \mathrm{ADF}-0.21 \mathrm{EE}-0.12 \mathrm{NDF}$ & 0.95 & 0.16 & $<0.01$ \\
\hline 8 & $\mathrm{DE}=17.44-0.20 \mathrm{EE}-0.12 \mathrm{NDF}+0.03 \mathrm{Starch}$ & 0.97 & 0.16 & $<0.01$ \\
\hline 9 & $\mathrm{ME}=9.15+0.15$ Starch & 0.76 & 0.38 & $<0.01$ \\
\hline 10 & $\mathrm{ME}=6.24+0.16 \mathrm{Starch}+0.13 \mathrm{CP}$ & 0.91 & 0.23 & $<0.01$ \\
\hline 11 & $\mathrm{ME}=12.82+0.11$ Starch $-0.26 \mathrm{ADF}$ & 0.94 & 0.20 & $<0.01$ \\
\hline 12 & $\mathrm{ME}=13.11+0.11$ Starch-0.26 ADF-0.07 EE & 0.96 & 0.16 & $<0.01$ \\
\hline 13 & $\mathrm{ME}=0.96 \mathrm{DE}-0.43$ & 0.80 & 0.35 & $<0.01$ \\
\hline
\end{tabular}

DE, digestible energy; ME, metabolizable energy; DM, dry matter; RSD, residual standard deviation; CF, crude fiber; ADF, acid detergent fiber; EE, ether extract; $\mathrm{CP}$, crude protein; NDF, neutral detergent fiber.

was the condensate of dilute sulfite liquor, which was used to steep the corn. Therefore, the temperature, the concentration of dilute sulfite liquor, the time of steeping and the kind of acidity regulator determined the quality of the corn steep liquor (Radley, 1976). High concentration of dilute sulfite liquor and long time of steeping would increase the sulfur content of CGF which negatively

Table 8. Analyzed chemical composition and energy content of corn gluten feeds in Exp. 2 (\%, DM)

\begin{tabular}{lcc}
\hline \multirow{2}{*}{ Items } & \multicolumn{2}{c}{ Corn gluten feed sources ${ }^{1}$} \\
\cline { 2 - 3 } & 11 & 12 \\
\hline $\mathrm{CP}$ & 22.19 & 19.17 \\
$\mathrm{EE}$ & 2.54 & 2.80 \\
$\mathrm{NDF}$ & 42.76 & 48.69 \\
$\mathrm{ADF}$ & 12.15 & 16.59 \\
Ash & 5.49 & 7.25 \\
Calcium & 0.04 & 0.06 \\
Total phosphorus & 0.85 & 1.09 \\
Starch & 13.47 & 8.34 \\
DE (MJ/kg) DE $=18.30-0.13$ NDF-0.22 EE & \\
Determined DE & 12.41 & 10.52 \\
Predicted DE & 12.18 & 11.35 \\
Difference & 0.23 & 0.84 \\
Relative deviation $(\%)$ & 0.93 & 3.84 \\
ME (MJ/kg) ME = 12.82+0.11 Starch-0.26 ADF & \\
Determined ME & 12.12 & 10.27 \\
Predicted ME & 11.14 & 9.42 \\
Difference & 0.98 & 0.84 \\
Relative deviation (\%) & 4.20 & 4.28 \\
\hline
\end{tabular}

$\mathrm{DM}$, dry matter; $\mathrm{CP}$, crude protein; $\mathrm{EE}$, ether extract; $\mathrm{NDF}$, neutral detergent fiber; ADF, acid detergent fiber; $\mathrm{DE}$, digestible energy; ME, metabolizable energy.

${ }^{1}$ Sources 11 and 12 were collected from Jilin and Hebei Provinces of China, respectively. influenced the appetite of CGF and the digestibility of CGF. CGF was mixed in different ratios of corn bran and steep liquor. Then, the mixture was dried at a constant temperature. A higher proportion of corn bran which was mainly made of fiber would increase the fiber content of CGF. At the same time, higher proportion of steep liquor which contained many amino acids would increase the CP and amino acids content of CGF. All these factors may influence the chemical composition and available energy of CGF (Cozannet et al., 2010), as well as the color variation from yellow-light brown to dark brown (Hoffman, 1991).

The variability of $\mathrm{CP}$ and fiber fraction among the 10 CGF sources was large and can be partly explained by the ratios of corn bran and steep liquor, which is in accordance with the previous report (Evvard, 1920). With the content of $\mathrm{CP}$ and $\mathrm{CF}$, CGF has traditionally been classified as a protein supplement feed for growing pigs with the substitution of corn up to $30 \%$ (Yen et al., 1971; Yen et al., 1974). Corn gluten feed can also be used as the primary protein and energy source for gestating sows (Honeyman and Zimmerman, 1990). The data of this research showed that more fiber means less crude protein. The content of NDF and ADF of sources 8 and 9 were 52.91 and $15.25 \%$ vs 41.74 and $11.90 \%$, but the content of CP was 17.21 vs $27.18 \%$, respectively. The data determined by Anderson et al. (2012) was also in accordance with this conclusion. At the same time, the large difference between ADF and NDF indicated that the fiber was largely hemicellulose (Hoffman, 1991). The EE of source 1 was higher than the others. This may be explained by the inclusion of corn germ, which is the rich-oil by-product of the corn-starch industry, in the CGF. The difference between the contents of calcium and sodium may be caused by the acidity regulator, including the most commonly used sodium hydroxide and calcium 
oxide (Radley, 1976). The calcium and sodium contents of source 5 were $0.15 \%$ and $710 \mathrm{mg} / \mathrm{kg}$. The calcium and sodium contents of source 7 were $0.21 \%$ and $285 \mathrm{mg} / \mathrm{kg}$. According to this we can conclude that the acidity regulators of sources 5 and 7 were sodium hydroxide and calcium oxide, respectively. The starch content of samples varied from 4.19 to $19.64 \%$, and the mean value of starch in the current study was slightly less than other literature data (Hoffman, 1991; Knudsen, 1997; Anderson et al., 2012). Corn bran was obtained after the starch was removed from the corn; the separation procedure or corn varieties could explain this difference. The different sulfur content of the 10 samples can be explained by the quality and quantity of corn steep liquor, which contains sulfur dioxide. The palatability of CGF can be negatively affected by the concentration of sulfur, as reported by Morrow et al. (2013). The mean value of GE was $18.81 \mathrm{MJ} / \mathrm{kg}$ of $\mathrm{DM}$, which is in accordance with Anderson et al. (2012) (18.98 MJ/kg of DM) but was slightly less than that of NRC (2012) (19.15 $\mathrm{MJ} / \mathrm{kg}$ of DM). The concentration of amino acids in the 10 samples of CGF differed but generally agreed with recently published values (Anderson et al., 2012).

\section{Digestible energy and metabolizable energy estimates for corn gluten feed in Exp.1}

With the wide range in CGF composition, DE and ME varied with differences of 2.48 and $2.96 \mathrm{MJ} / \mathrm{kg}$ of $\mathrm{DM}$ among CGF. However, the differences were insignificant ( $>0.05$ ) with an average of 11.64 and $10.72 \mathrm{MJ} / \mathrm{kg}$ of DM, respectively. Sources 4 and 8 had the maximal and minimal DE (12.85 vs $10.37 \mathrm{MJ} / \mathrm{kg}$ of DM) and ME (12.49 vs 9.53 $\mathrm{MJ} / \mathrm{kg}$ of DM). Digestible energy and ME of the literature data are in accordance with this study (Yen et al., 1974; Anderson et al., 2012), but the DE and ME described by Noblet et al. (1993) were less than that obtained in the current study. For the better utilization of fiber in sows, the $\mathrm{DE}$ and ME of CGF were higher than the values for finishing pigs in this research (Honeyman and Zimmerman, 1991). The ATTD of energy was not significantly different among the 10 CGF sources ( $p>0.05$ ). The ME to DE ratio varied from 85.61 to $97.16 \%$, with an average of $92.09 \%$, which was in accordance with the literature data of $92.73 \%$, determined by Anderson et al. (2012). The ME to DE ratio of corn bran was nearly $98.44 \%$, which was higher than the value of CGF. This could have been due to the high level of $\mathrm{CP}$ and the imbalance of the amino acid composition of CGF (Pedersen et al., 2007).

\section{Correlation and prediction equation in Exp. 1}

With a dynamic equation, CGF can be used more efficiently while reducing the time and high cost of animal experiments (Noblet and Perez, 1993). Digestible energy and ME prediction equations for diets containing CGF had been published previously (Noblet et al., 1993; Noblet and Perez, 1993; Noblet et al., 1994; Le Goff and Noblet, 2001). But the equations cannot be used to predict feedstuffs whose digestibility of cell wall and EE are significantly different from the mean values in that study (Noblet and Perez, 1993). Additionally, there was significant interaction between the dietary ingredients (Noblet et al., 1993; Le Goff and Noblet, 2001). The DE and ME of corn byproducts including CGF predicted from chemical analysis has been done by Anderson et al. (2012), but in this experiment there was only one CGF sample. Therefore, the prediction equation of available energy of CGF should be established from the CGF sources with representation and difference.

The CP and starch content had a positive effect on DE and $\mathrm{ME}$, but the fiber content and GE were negatively correlated with them. Starch has a high DE and ME, which can reach 17.09 and $17.08 \mathrm{MJ} / \mathrm{kg}$ of DM, respectively, and provide higher efficiency for ME (Noblet, 2000). CGF is a coproduct of the starch industry. Therefore, the content of starch, which was determined by the level of processing, was extremely important to the $\mathrm{DE}$ and ME values. The fiber content, including $\mathrm{CF}, \mathrm{NDF}$ and $\mathrm{ADF}$, had negative effects on DE and ME (Noblet, 2000). Corn fiber was the major part of CGF, and it can not be fully digested by pigs. Le Goff and Noblet (2001) and Noblet (1993) reported that the ATTD of energy decreased linearly when the NDF content of the diet increased. The ADF fraction alone accounted for most of the variation of barley energy content (Fairbairn et al., 1999). For distillers dried grains with solubles, the lower concentrations of ADF and NDF might contribute to the greater DE and ME (Pedersen et al., 2007). In addition, Noblet and Perez (1993) indicated that the available energy coming from fiber digestion was negligible when compared with the loss of endogenous protein and fat. Therefore, the low degradation and negative effect on the digestibility of other chemical constituents led to the negative coefficient between fiber and available energy.

The GE content had a negative correlation on the EE, $\mathrm{CP}, \mathrm{DE}$, and $\mathrm{ME}$ values but a positive correlation on the fiber content, which conflicted with previously published data (Noblet and Perez, 1993; Pedersen et al., 2007; Anderson et al., 2012). A possible explanation for the negative coefficient of $\mathrm{EE}$ is that the lower crude fat had little contribution to the GE, and it had statistical meaning but no biological meaning. As for the positive coefficient of fiber content, it may be because the fiber of CGF contributed greatly to GE, although the $\mathrm{DE}$ and $\mathrm{ME}$ of fiber were low.

Considering the accuracy of prediction equations of DE and $\mathrm{ME}$, the convenience and the expense of measuring indexes, equations 6 and 11 were selected to be the best two 
for DE and ME, respectively. However, if there is no ability to test the starch content, equation 13 is proper to predict the ME value.

\section{The accuracy of the predicted equations in Exp. 2}

The purpose of this experiment was to use another two CGF sources that were different from the 10 CGF samples in Exp. 1 and conducted in a different time with Exp. 1 in order to validate the accuracy of the prediction equations from Exp. 1. Only in this way, the equations can be used with different CGF sample and experimental time.

In Exp. 1, equations 6 ( $\mathrm{DE}=18.30-0.13 \mathrm{NDF}-0.22 \mathrm{EE})$ and $11(\mathrm{ME}=12.82+0.11$ Starch-0.26 $\mathrm{ADF})$ were selected to be the best for $\mathrm{DE}$ and $\mathrm{ME}$, respectively. The relative deviations of the determined available energy and the predicted ones were less than $5 \%$ which indicated that the accuracy of the two predicted equations were in an acceptable range ( $\mathrm{Li}$ et al., 2012).

In the future, more samples of CGF should be added to establish the prediction equations with higher accuracy and wider application. In addition, more research about NE prediction equations should also be conducted.

\section{ACKNOWLEDGMENTS}

This research was financially supported by the Special Public Sector Fund in Agriculture (200903006) and Research and Demonstration on Pig Health and Management (2012BAD39B00).

\section{REFERENCES}

AOAC. 2000. Official Methods of Analysis, 17th ed. Association of Official Analytical Chemists, Arlington, VA, USA.

Adeola, O. 2001. Digestion and balance techniques in pigs. In: Swine Nutrition, 2nd ed. (Ed. D. J. Lewis and L. L. Southern). CRC Press, New York, pp. 903-916.

Anderson, P. V., B. J. Kerr, T. E. Weber, C. J. Ziemer, and G. C. Shurson. 2012. Determination and prediction of digestible and metabolizable energy from chemical analysis of corn coproducts fed to finishing pigs. J. Anim. Sci. 90:1242-1254.

Castaing, J., R. Coudure, J. Fekete, and F. Grosjean. 1990. Use of maize gluten feed for weaned piglets and meat pigs. Journées Rech. Porc. 22:159-165.

Cozannet, P., Y. Primot, C. Gady, J. P. Métayer, M. Lessire, F. Skiba, and J. Noblet. 2010. Energy value of wheat distillers grains with solubles for growing pigs and adult sows. J. Anim. Sci. 88:2382-2392.

De Godoy, M. R. C., L. L. Bauer, C. M. Parsons, and G. C. Fahey. Jr. 2009. Select corn coproducts from the ethanol industry and their potential as ingredients in pet foods. J. Anim. Sci. 87:189199.

Evvard, J. M. 1920. Corn gluten feed for fattening fall pigs. J. Anim. Sci. 1920:70-74.

Fairbairn, S. L., J. F. Patience, H. L. Classen, and R. T. Zijlstra.
1999. The energy content of barley fed to growing pigs: Characterizing the nature of its variability and developing prediction equations for its estimation. J. Anim. Sci. 77:15021512.

Ham, G. A., R. A. Stock, T. J. Klopfenstein, and R. P. Huffman. 1995. Determining the net energy value of wet and dry corn gluten feed in beef growing and finishing diets. J. Anim. Sci. 73:353-359.

Hoffman, P. C. 1991. Corn gluten feed. Bulletin No. A3518. University of Wisconsin-Madison.

Honeyman, M. S. and D. R. Zimmerman. 1990. Long-term effects of corn gluten feed on the reproductive performance and weight of gestating sows. J. Anim. Sci. 68:1329-1336.

Honeyman, M. S. and D. R. Zimmerman. 1991. Metabolizable energy of corn gluten feed and apparent digestibility of the fiberous conponents for gestating sows. Anim. Feed Sci. Technol. 35:131-137.

Hull, S. R., B. Y. Yang, D. Venzke, K. Kulhavy, and R. Montgomery. 1996. Composition of corn steep water during steeping. J. Agric. Food Chem. 44:1857-1863.

Ji, Y., L. Zuo, F. Wang, D. Li, and C. Lai. 2012. Nutritional value of 15 corn gluten meals for growing pigs: Chemical composition, energy content and amino acid digestibility. Arch. Anim. Nutr. 66:283-302.

Bach Knudsen, K. E. 1997. Carbohydrate and lignin contents of plant materials used in animal feeding. Anim. Feed Sci. Technol. 67:319-338.

Le Goff, G. and J. Noblet. 2001. Comparative total tract digestibility of dietary energy and nutrients in growing pigs and adult sows. J. Anim. Sci. 79:2418-2427.

Li, J. T., D. F. Li, J. J. Zang, W. J. Yang, W. J. Zhang, and L. Y. Zhang. 2012. Evaluation of energy digestibility and prediction of digestible and metabolizable energy from chemical composition of different cottonseed meal sources fed to growing pigs. Asian Australas. J. Anim. Sci. 25:1430-1438.

Morrow, L. A, T. L. Felix, F. L. Fluharty, K. M. Daniels, and S. C. Loerch. 2013. Effects of sulfur and acidity on performance and digestibility in feedlot lambs fed dried distillers grains with solubles. J. Anim. Sci. 91:2211-2218.

Noblet, J. 2000. Digestive and metabolic utilization of feed energy in swine: Application to energy evaluation systems. J. Appl. Anim. Res. 17:113-132.

Noblet, J., H. Fortune, C. Dupire, and S. Dubois. 1993. Digestible, metabolizable and net energy values of 13 feedstuffs for growing pigs: Effect of energy system. Anim. Feed Sci. Technol. 42:131-149.

Noblet, J., H. Fortune, X. S. Shi, and S. Dubois. 1994. Prediction of net energy value of feeds for growing pigs. J. Anim. Sci. 72:344-354.

Noblet, J. and J. M. Perez. 1993. Prediction of digestibility of nutrients and energy values of pig diets from chemical analysis. J. Anim. Sci. 71:3389-3398.

NRC. 2012. Nutrient Requirements of Swine. 11th Ed. National Research Council, Academy Press. Washington, DC, USA.

Pedersen, C., M. G. Boersma, and H. H. Stein. 2007. Digestibility of energy and phosphorus in ten samples of distillers dried grains with solubles fed to growing pigs. J. Anim. Sci. 85:1168-1176.

Radley, J. A. 1976. Starch Production Technology. Applied 
Science Publishers Ltd., London.

SAS. 1999. SAS User's Guide: Statistics (Version 8.01 ed.). SAS Inst. Inc., Cary, NC, USA.

Scott, T., T. Klopfenstein, R. Stock, and M. Klemesrudl. 1997. Evaluation of corn bran and corn steep liquor for finishing steers. Nebraska Beef Cattle Reports pp.72-74.

Stock, R. A., J. M. Lewis, T. J. Klopfenstein, and C. T. Milton. 1999. Review of new information on the use of wet and dry milling feed by-products in feedlot diets. J. Anim. Sci. 77:1-12.

Thiex, N. J., S. Anderson, and B. Gildemeister. 2003. Crude fat, diethyl ester extraction, in feed, cereal grain, and forage (Randall/Soxtec/submersion method): Collaborative study. J. AOAC. Int. 86:888-898.
Van Soest, P. J., J. B. Robertson, and B. A. Lewis. 1991. Methods for dietary fiber, neutral detergent fiber, and non-starch polysaccharides in relation to animal nutrition. J. Dairy Sci. 74:3583-3597.

Xiong, Y., S. J. Bartle, and R. L. Preston. 1990. Improved enzymatic method to measure processing effects and starch availability in sorghum grain. J. Anim. Sci. 68:3861-3870.

Yen, J. T., D. H. Baker, B. G. Harmon, and A. H. Jensen. 1971. Corn gluten feed in swine diets and effect of pelleting on tryptophan availability to pigs and rats. J. Anim. Sci. 33:987991.

Yen, J. T., J. D. Brooks, and A. H. Jensen. 1974. Metabolizable energy value of corn gluten feed. J. Anim. Sci. 39:335-337.

Young, L. G., G. C. Ashton, and G. C. Smith. 1977. Estimating the energy value of some feeds for pigs using regression equations. J. Anim. Sci. 44:765-771. 